\title{
Expression in normals and in subjects with schizophrenia of a novel gene fragment originally isolated from monozygotic twins discordant for schizophrenia
}

\author{
Mercedes Zumárraga ${ }^{1}$, Isabel Andía ${ }^{1}$, Ricardo Dávila ${ }^{1}$, Jeannette C. Miller ${ }^{2}$ and Arnold J. Friedhoff ${ }^{2}$ \\ ${ }^{1}$ Servicio Vasco de Salud, Hospital Psiquiátrico de Zamudio, Departamento de Investigación \\ Neuroquímica, Zamudio, Vizcaya, Spain. \\ ${ }^{2}$ New York University Medical School, Department of Psychiatry, New York, NY, USA.
}

\begin{abstract}
Differentially expressed clones from subtracted cDNA libraries of a pair of monozygotic twins discordant for schizophrenia have been reported in the literature. The clones were expressed in lymphocytes from the healthy twin, but not from the schizophrenic twin. In the current study, we assessed the expression of one of these clones, oksc12b, in 10 normal controls and in 10 patients who met DSM-IV criteria for schizophrenia and had never received neuroleptic medication. We hypothesized that this clone would be differentially expressed in normal controls and in the schizophrenic patients, and that its expression could be a peripheral marker of the disease. Lymphocytes were isolated and total RNA was purified, reverse-transcribed, and quantified by two PCR methods. In the first PCR assay, oksc12b expression was measured relative to beta-actin gene expression. The second PCR assay consisted of a competitive procedure using a heterologous DNA internal standard. Neither method confirmed any difference in oksc12b expression between schizophrenic patients and normal controls. Subtypes of schizophrenia or the general heterogeneity of this syndrome may explain the discrepancy found. It is also possible that the differentially expressed clones are present in discordant monozygotic twins, but not in other patients.
\end{abstract}

Key words: monozygotic twins, mRNA, schizophrenia.

Received: December 13, 2002; Accepted: September 10, 2003.

Introduction

Subtractive hybridization can be used to identify differences in gene activity between discordant monozygotic twins (Travis et al., 1987). Novel, differentially expressed clones have been isolated from subtracted lymphocyte cDNA libraries of a pair of twins discordant for schizophrenia (Friedhoff, et al. 1995). The clones were expressed in lymphocytes from the healthy twin, but not in lymphocytes from the twin with schizophrenia. The authors speculated that those mRNAs might code for some proteins which protected the healthy twin against schizophrenia. It is noteworthy that genes which have an important function in other tissues have been found to be lowly expressed in lymphocytes and without a known function. Such is the case of the dystrophin gene which plays a role in muscles (Chelly et al., 1988), of dopaminergic receptors in the brain (Bondy et al. 1996; Nagai et al. 1993; Takahashi et al. 1992), and of glial protein RNAs, in the peripheral nervous system (Riol et al. 1997).

Send correspondence to Mercedes Zumárraga. Arteaga Auzoa 45, 48170 Zamudio, Vizcaya, Spain. E-mail: Ineuroquimica.zamudio @ hzam.osakidetza.net.
There are several peripheral markers which, under controlled conditions, may represent what occurs in the brain in psychiatric diseases. We (Dávila et al., 1996) and other authors have found that the variations in the plasma concentrations of homovanillic acid are a good predictor of the response to neuroleptics in schizophrenic patients, despite the fact that this dopamine metabolite has a central and peripheral origin. Several serotonin parameters in platelets are also good indicators of antidepressant efficacy in depressed patients (Bakish et al., 1997). Morevoer, it has been reported (Nagai et al., 1996) that the expression of the dopamine D3 receptor gene is diminished in lymphocytes from patients with Parkinson's disease, and that a decreased D3 expression correlates with the severity of the symptoms.

Coupled reverse transcription (RT) - polymerase chain reaction (PCR) is a highly sensitive method to assess gene expression, but, as it involves two enzymatic reactions, one of which with an exponential behavior, its reproducibility is low. Therefore, internal standards must be used to control the efficiencies of both the RT and the 
PCR processes. The internal standard could be a synthetic homologous RNA added before or after total RNA purification, a synthetic DNA used to control only PCR efficiency, and/or an endogenous gene like beta-actin, whose expression is supposed to be conserved in each tissue.

We chose a double method of quantification, one involving beta-actin expression to control RNA extraction, RT and PCR, and the other using heterologous DNA to quantify the absolute expression of our gene in a competitive PCR assay.

In the original study, the oksc $12 \mathrm{~b}$ gene was expressed in the non-schizophrenic but not in the schizophrenic twin, so our working hypothesis was that the oksc $12 \mathrm{~b}$ gene would be differentially expressed in normal controls and in schizophrenics free of medication, and that the lack of expression of this gene could be a peripheral marker for the disease.

\section{Material and Methods}

A group of 10 normal controls was selected, 6 women and 4 men, mean age 32 years (s.d. $=6$ ). They had no known illnesses and they were not receiving any medication at the time of the study. All gave $40 \mathrm{~mL}$ of blood for RNA analysis.

The group of 10 patients, 6 women and 4 men, mean age 24 years (s.d. $=5$ ), met DSM-IV criteria for schizophrenia. They had never taken neuroleptic medication and were not receiving any medication at the time of the study. All were informed about the investigation and consented to participate. All gave $20 \mathrm{ml}$ of blood for RNA analysis.

\section{Isolation of total RNA}

Blood was obtained in heparinized tubes, lymphocytes were isolated by separation on Ficoll-Paque (Pharmacia), and RNA was immediately isolated following the method of Chomczynski and Sacchi (1987). RNAs were incubated with RNAse-free DNAse (20 U/10 $\mu$ g RNA) in the presence of $200 \mathrm{U}$ of RNAsin Ribonuclease Inhibitor (Promega) for $30 \mathrm{~min}$ at $37^{\circ} \mathrm{C}$, to eliminate any possible DNA contamination. The amount of RNA was determined by optical absorption at $260 \mathrm{~nm}$, and its integrity was confirmed in a denaturing 1.2\% agarose gel in MOPS stained with ethidium bromide.

\section{Reverse transcription}

$2 \mu \mathrm{g}$ of RNA were incubated with $1 \mu \mathrm{g}$ of oligo-dT (15) primer for $5 \mathrm{~min}$ at $72{ }^{\circ} \mathrm{C}$. After $5 \mathrm{~min}$ in an ice bath, samples were incubated with $100 \mathrm{U}$ of M-MLV reverse transcriptase, $10 \mathrm{U}$ of RNAsin, and $0.5 \mathrm{mM}$ each of four dNTPs for $1 \mathrm{~h}$ at $37^{\circ} \mathrm{C}$. After inactivation at $95{ }^{\circ} \mathrm{C}$ for 3 min, cDNAs were stored at $-20{ }^{\circ} \mathrm{C}$ until analysis.

\section{PCR reaction}

The cDNA studied consisted of a 201-bp fragment cloned in a cDNAII vector (Invitrogen); we selected a pair of primers using Primer Premier software (Biosoft International), which yielded a PCR fragment of $160 \mathrm{bp}$. The sense primer was 5'-GCTTTATCAGGCCAGGCACAGT, and the antisense primer was 5'-CCACCACCAATGGCTAA GTTTT. The beta-actin (ba) gene was amplified with the sense primer 5'-AAGAGAGGCATCCTCACCCT and the antisense primer 5'-TACATGGCTGGGGTGTTGAA, which rendered a PCR product of $218 \mathrm{bp}$.

A pair of composite primers was designed to generate a nonhomologous competitor DNA fragment. These primers contained the primers for the target sequence oksc $12 \mathrm{~b}$ pasted to the b-actin primers, and the PCR product was 262-bp long. The competitor standard was generated by two successive PCR amplifications of human lymphocyte cDNA, adding $\alpha^{32} \mathrm{P}-\mathrm{dCTP}$ to quantify the amount of final product. The first PCR product was generated with the composite primers, and the second one using the above product as a template with the oksc $12 \mathrm{~b}$ primers. The final competitor was purified on an agarose gel and quantified by measuring the $\alpha^{32} \mathrm{P}-\mathrm{dCTP}$ incorporated.

The PCR reaction was performed in a $50 \mu \mathrm{L}$ volume containing 1xPCR buffer $\left(1.6 \mathrm{mM}\left(\mathrm{NH}_{4}\right)_{2} \mathrm{SO}_{4}, 67 \mathrm{mM}\right.$ Tris- $\mathrm{HCl}\left(\mathrm{pH} 8.8\right.$ at $\left.25{ }^{\circ} \mathrm{C}\right), 0.01 \%$ Tween-20), $1.5 \mathrm{mM}$ $\mathrm{MgCl}_{2}, 100 \mu \mathrm{M}$ of each dNTP, $1.25 \mathrm{U}$ of BioTaq DNA polymerase, ten million cpm of $\alpha^{32} \mathrm{P}-\mathrm{dCTP}, 0.3 \mu \mathrm{M}$ of each oksc $12 \mathrm{~b}$ primer, and $0.75 \mu \mathrm{M}$ of each beta-actin primer, in a Perkin Elmer/Cetus thermocycler.

The PCR conditions involved initial denaturing at $95{ }^{\circ} \mathrm{C}$ for $3 \mathrm{~min}$, followed by 25 cycles of denaturing at $95^{\circ} \mathrm{C}$ for $1 \mathrm{~min}$, annealing at $62{ }^{\circ} \mathrm{C}$ for $30 \mathrm{~s}$, extension at $72{ }^{\circ} \mathrm{C}$ for $30 \mathrm{~s}$, and a final extension at $72{ }^{\circ} \mathrm{C}$ for $7 \mathrm{~min}$.

\section{PCR relative to beta-actin gene}

A dilution series of each cDNA from lymphocytes, containing an equivalent of 5 to $60 \mathrm{ng}$ of RNA and 10 million cpm of $\alpha^{32} \mathrm{P}-\mathrm{d}-\mathrm{CTP}$, were amplified in the presence of $0.3 \mu \mathrm{M}$ primers for oksc $12 \mathrm{~b}$ plus $0.075 \mu \mathrm{M}$ primers for the beta-actin gene. The beta-actin gene produced a 218 -bp PCR fragment that was separated from the 160-bp oksc $12 \mathrm{~b}$ fragment on a $6 \%$ polyacrilamide gel or in a $2 \%$ agarose gel. The gel was stained in ethidium bromide and visualized under UV light. Bands were excised and the incorporated radionuclide was counted in a scintillation counter. For each sample, a regression line of the logarithm of radionuclide incorporation (cpm) against the logarithm of RNA amount was plotted. The relative response of oksc $12 \mathrm{~b}$ to beta-actin, measured in $25 \mathrm{ng}$ of RNA, was used to compare expression in patient and control samples.

The measurement of beta-actin alone, expressed as the percentage of radionuclide incorporation per unit RNA 
weight, was used to correct values obtained by competitive PCR.

\section{Competitive PCR}

Each sample was amplified in a series of tubes containing a fixed amount of cDNA from lymphocytes, equivalent to $300 \mathrm{ng}$ of original RNA, and progressively larger amounts of competitor, from 0.002 to 4.63 attomoles. Products were separated on $2 \%$ agarose gel containing ethidium bromide. Bands were cut and radionuclide incorporation was measured; an aliquot of each reaction was also assessed by HPLC (Andía et al., 2001). The amount of oksc $12 \mathrm{~b}$ in each sample was calculated by plotting the logarithm of the oksc12b/competitor ratio against the logarithm of attomoles of competitor. The point on the line where the ordinate value equaled the logarithm of 160/262 corresponded to the point where each had the same number of molecules. The amount of oksc $12 \mathrm{~b}$ in attomoles found with this method was normalized with respect to the amount of beta-actin obtained in experiments to correct the variability of the process of RNA purification and RT.

\section{Results}

We first attempted to quantify RT performance by adding a d-NTP marked with ${ }^{32} \mathrm{P}$ of highly specific activity (Pennetier et al., 1992). After the reaction we tried to separate cDNA-incorporated radionuclide from free radionuclide using different methods: precipitation with $10 \%$ TCA followed by filtration, or separation in columns selective for the number of bases (Chromaspin 10, Clontech; Microcon 30, Millipore). These methods were unable to differentiate blank (for which water was used instead of template RNA) and samples. Therefore, we decided to correct performance by measuring relative beta-actin gene expression.

In 25 cycles, using RNA amounts from $5 \mathrm{ng}$ to $60 \mathrm{ng}$, we found that PCR reactions in which beta-actin and oksc 12 b were measured simultaneously were always in an exponential phase. Figure 1 shows a $\%$ agarose gel separation of PCR products of the oksc12b gene (160 bp) and of the beta-actin gene (218 bp), after amplification of cDNA from a normal control. After trying beta-actin primer concentrations ranging from $0.025 \mu \mathrm{M}$ to $0.1 \mu \mathrm{M}$ under our conditions, we found that both products were easily measured at a concentration of $0.075 \mu \mathrm{M}$. Analysis of the same sample on 10 different days yielded a cv\% of $20 \%$ for the oksc $12 \mathrm{~b} / \mathrm{ba}$ ratio and of $18 \%$ for measurements of betaactin alone.

Figure 2 shows a 2\% agarose gel separation of PCR products corresponding to the oksc12b gene (160 bp) and the competitor product (262bp). The efficiency of the competitor in the PCR reaction was $59 \%(n=6)$ and of oksc $12 \mathrm{~b}$, $56 \%$. Analysis of the same sample on 6 different days yielded a cv\% of $17 \%$.

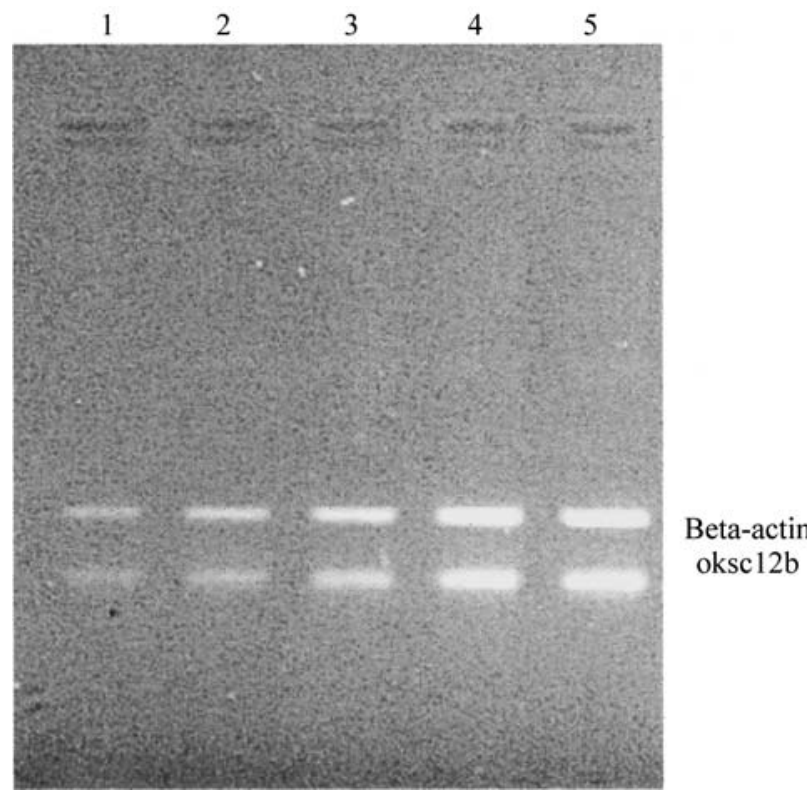

Figure 1 - $2 \%$ agarose gel separation of RT-PCR fragments corresponding to oksc12b gene (169 bp) and beta-actin gene ( $218 \mathrm{bp}$ ) amplified from cDNA of a normal control. Lanes 1 to 5 correspond to an equivalent of 5 , $10,20,40$, and 60 ng of RNA.

The values of the measurements made in cDNA samples from normal controls and schizophrenic patients are shown in Table 1. We found no significant differences in the average values of any measurement of oksc12b gene expression between patients and controls. A comparison of the standard deviations of measurements of relative betaactin gene expression showed a greater dispersion of values in schizophrenic patients $(\mathrm{F}=0.059, \mathrm{p}<0.001)$.

The values obtained by plotting oksc $12 \mathrm{~b}$ expression in dilution samples with respect to beta-actin in the overall group of samples studied showed a weak correlation $(\mathrm{r}=0.577, \mathrm{R}$-square $=33 \%)$ with absolute quantification measurements by competitive PCR. However, a correlation was found when we corrected the values obtained by quan-

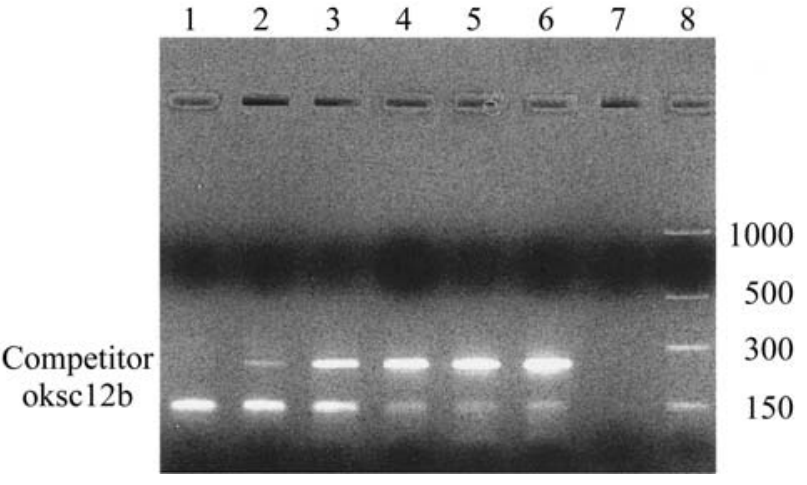

Figure 2 - 2\% agarose gel separation of RT-PCR products corresponding to the oksc12b gene (160 bp) and the competitor DNA (262bp). Lanes 1 to 6 correspond to an equivalent of $300 \mathrm{ng}$ of cDNA from a normal control amplified in the presence of $0.002,0.023,0.23,1.16,2.31$, and 4.63 attmol of competitor. Lane 8 corresponds to a molecular weight marker containing $150,300,500$ and $1000 \mathrm{bp}$ 
Table 1 - Assessment of the oksc12b gene expression after RT-PCR assays of RNA from lymphocytes of control subjects and schizophrenic patients

\begin{tabular}{|c|c|c|}
\hline & Controls & Schizophrenics \\
\hline $\begin{array}{l}\text { Competitive PCR (attmol } \\
\text { oksc12b/ug RNA) }\end{array}$ & $4.27 \pm 3.90$ & $4.89 \pm 4.53$ \\
\hline Titration assay (oksc12b/ba) & $1.46 \pm 1.00$ & $1.96 \pm 1.87$ \\
\hline $\begin{array}{l}\text { attmol oksc } 12 \mathrm{~b} / \% \mathrm{cpm} \text { ba } \\
\text { incorporated }\end{array}$ & $0.66 \pm 0.44$ & $1.45 \pm 1.44^{*}$ \\
\hline
\end{tabular}

*Significant difference between standard deviations, $\mathrm{F}=0.059, \mathrm{p}<0.001$.

titative PCR for beta-actin expression ( $r=0.864$, R-square $=75 \%$ ). This may indicate variations in the efficiency of $\mathrm{RT}$ in different samples.

\section{Discussion}

An endogenous gene was chosen as the control for the efficiency of RT and the initial RNA measurement. RNA measurement by optical absorbance can give an approximate value; however, other products of purification, such as proteins, contaminating DNA, or partially degraded RNA, that also absorb at this wavelength may contribute significantly to producing inaccurate quantitation. Assay of a gene like beta-actin, which has been extensively used in the literature, is more useful for comparative studies. We adapted the measurement of beta-actin, which has a much higher level of expression than oksc12b, to the measurement of our gene by diluting the concentration of the betaactin primers to one-fourth. This option, as opposed to the addition of beta-actin primers after a series of cycles, prevents cross-contamination and can be easily used for the study of genes with very different levels of expression.

Synthesis of a double-strand DNA competitor is simple, its quantification by radioactive incorporation is precise, and its conservation is stable. By establishing a relationship with the expression of another gene, more reliable, semi-quantitative information about the level of expression is provided than by using the titration technique. The combination of relative and competitive PCR will allow us to compare the expression of this gene with others that are also expressed in lymphocytes, thus establishing a true quantitative comparison between them. It should be pointed out that in this case, or in HPLC analysis, the amount of PCR products is not proportional to the number of strands, as occurs when using marked primers or hybridization. Consequently, competitor and template amounts are equal when the relation between their logarithms is equal to the relationship between the number of their bases, in this case 262 and 160.

In the sample populations studied, we detected no significant differences in the levels of expression of the oksc12b gene between controls and patients with schizophrenia. These results did not confirm the difference reported by the original study. During the development of our study, Friedhoff et al. (personal communication) measured again the expression of the 10 genes that were originally found to be differentially expressed. In lymphocytes obtained 2 years later from the same pair of twins, six of these genes were found differentially expressed in this new measurement, among them the oksc $12 \mathrm{~b}$ clone. The expression of oksc12b was measured in the Friedhoff studies by ribonuclease protection assay (RPA), a technique which is much less sensitive than RT-PCR. This may explain, in part, the lack of differential expression of oksc12b in the present study.

Familial versus non-familial schizophrenia (Dávila et al., 1995), subtypes of schizophrenia (Dávila et al., 1996) and the general heterogeneity of the syndrome may explain the discrepancy between the two studies. The fact that our gene-expression values were more dispersed in the patient sample than in controls may imply that there was more than one population in the study group. There are a number of findings suggesting that biological parameters vary more in schizophrenic patients than in healthy controls, especially parameters related to dopaminergic transmission (Syvälahti et al. 2000); these variations may reflect a dysregulated or labile system. Our original design did not allow us to address this issue, nor to establish a relation with parameters such as diagnosis, symptoms, and clinical evolution.

It also would be interesting to study a sample of monozygotic twins discordant for schizophrenia, as in the original study (Friedhoff et al., 1995). In a study of DNA from twins discordant for schizophrenia, Tsujita et al. (1998) found differences in the presence of Notl restrictions sites with respect to control twins; these differences may be associated with different levels of methylation/ demethylation of sites near the promoter of different genes, thus modifying the expression of these genes. It has been hypothesized that DNA-methylation mediated processes, among other epigenetic factors, may be of etiologic importance in schizophrenia (Petronis et al., 1999). There may also be a detectable difference in oksc $12 \mathrm{~b}$ gene expression in patients with a longer clinical evolution. Such a modification would not be due to the disease itself, but arise as a consequence of the evolution of the disease. In our sample, in contrast with the twins, patients were young people with a short evolution of the illness. Neuroleptic treatment does not appear to be a significant factor, because neither the schizophrenic twin of the original study nor the patients in this study had received neuroleptic treatment.

Regardless of the results obtained, it seems that lymphocytes may be useful for the study of disturbances in the brain. Substances detected in human lymphocytes include, among others, mRNAs corresponding to the kappa opioid receptor (Takahashi et al., 1992), an astroglial marker (Riol et al., 1997), and the dopaminergic receptors D3 (Nagai et al., 1993), D4 (Bondy et al., 1996) and D5 (Takahashi et al., 1992), which have a known function in the nervous sys- 
tem, but no apparent function in lymphocytes. The assessment of mRNA in lymphocytes may serve as a peripheral marker of disease. In the brain and lymphocytes of schizophrenic patients, reduced expression of mitochondrial reductases has been found after flupentixol treatment (Whatley et al., 1998). In patients with Parkinson's disease, a reduction in the expression of the dopaminergic receptor D3 has been found (Nagai et al., 1996) in lymphocytes, which correlates with the severity of symptoms.

\section{Acknowledgements}

Financed in part by FIS grant $n^{\circ} 99 / 0716$ and by a Harriet G. \& Esteban Vicente Charitable Trust Research Grant

\section{References}

Andía I, Zumárraga M, Dávila R, Miller JC and Friedhoff AJ (2001) Quantitative determination of gene expression in human lymphocytes assessed by reverse transcriptionpolymerase chain reaction coupled to high-performance liquid chromatography. J Chromatogr B 761:237-246.

Bakish D, Cavazzoni P, Chudzik J, Ravindran A and Hardine PD (1997) Effects of selective serotonin reuptake inhibitors on platelet serotonin parameters in major depressive disorder. Biol Psychiatry 41:184-190.

Bondy B, Jonge S, Pander S, Primbs J and Ackenheil M (1996) Identification of dopamine D4 receptor mRNA in circulating human lymphocytes using nested polymerase chain reaction. J Neuroimmunol 71:130-144.

Chelly J, Kaplan JC, Maire P, Gautron S and Kahn A (1988) Transcription of the dystrophin gene in human muscle and non muscle tissue. Nature 333:858-860.

Chomczynski P and Sacchi N (1987) Single-step method of RNA isolation by acid guanidinium thiocyanate-phenolchloroform extraction. Anal Biochem 162:156-159.

Chuang LF, Chuang TK, Killam KF Jr, Qiu Q, Wang XR, Lin JJ, Kung HF, Sheng W, Chao C, Yu L and Chuang RY (1995) Expression of kappa opioid receptors in human and monkey lymphocytes. Biochem Biophys Res Commun 209:10031010.

Dávila R, Zumárraga M, Gonzalez-Torres MA, Andía I, Zamalloa MI, Basterreche N, Guimón J and Friedhoff AJ (1995) Schizophrenia: gender, family risk, and plasma homovanillic acid. Am J Med Genet (Neuropsychiatr Genet) 60:154-156.

Dávila R, Zumárraga M, Andía I, Almoguera-Abad A and Friedhoff AJ (1996) Early Increase of Plasma HVA during neuroleptic treatment: A tool for outcome prediction and for subtyping of schizophrenia. In: Friedhoff AJ and Amin F (eds) Plasma homovanillic acid: implications for presynaptic dopamine dysfunction. American Psychiatric Press Inc, Washington, pp 89-102.

Friedhoff AJ, Miller JC and Basham DA (1995) A subtracted probe derived from lymphocytes of twins discordant for schizophrenia hybridizes to selective areas of rat brain. Biol Psychiatry 37:127-131.

Nagai Y, Ueno S, Saeki Y, Soga F, Hirano M and Yanagihara T (1996) Decrease of the D3 dopamine receptor mRNA expression in lymphocytes from patients with Parkinson disease. Neurology 46:791-795.

Nagai Y, Ueno S, Saeki Y, Soga F and Yanagihara T (1993) Expression of the D3 dopamine receptor gene and a novel variant transcript generated by alternative splicing in human peripheral blood lymphocytes. Biochem Biophys Res Commun 194:368-374.

Pennetier C, Delassus S, Darche S, Saucher C and Kourilski P (1992) Quantitative titration of nucleic acids by enzymatic amplification reactions run to saturation. Nucleic Acids Res 21:577-583.

Petronis A, Paterson AD and Kennedy JL (1999) Schizophrenia: an epigenetic puzzle? Schizophr Bull 25:639-855.

Riol H, Tardy M, Rolland B, Levesque G and Murthy MR (1997) Detection of the peripheral nervous system (PNS)-type glial fibrillary acidic protein (GFPA) and its mRNA in human lymphocytes. J Neurosci Res 48:53-62.

Syvälahti EKG, Räkköläinen V, Aaltonen J, Lehtinen V and Hietala J (2000) Striatal D2 dopamine receptor density and psychotic symptoms in schizophrenia: a longitudinal study. Schizophr Res 43:159-161.

Takahashi N, Nagai Y, Ueno S, Saeki Y and Yanahihara T (1992) Human peripheral blood lymphocytes express D5 dopamine receptor gene and transcribe the two pseudogenes. Febs Lett 314:23-25.

Travis GH, Naus CG, Morrison JH, Bloom FE and Sutcliffe JG (1987) Subtractive cloning of complementary DNAs and analysis of messenger RNAs with regional heterogenous distribution in primate cortex. Neuropharmacology 26:845854.

Tsujita T, Niikawa N, Yamashita H, Imamura A, Hamada A, Nakane Y and Okazaki Y (1998) Genomic discordance between monozygotic twins discordant for schizophrenia. Am J Psychiatry 155:422-424.

Whatley SA, Curti D, Das Gupta F, Ferrier IN, Jones S, Taylor C and Marchbanks RM (1998) Superoxide, neuroleptics and the ubiquinone and cytochrome b5 reductases in brain and lymphocytes from normals and schizophrenic patients. Mol Psychiatry 3:227-237.

Editor: Angela M. Vianna-Morgante 